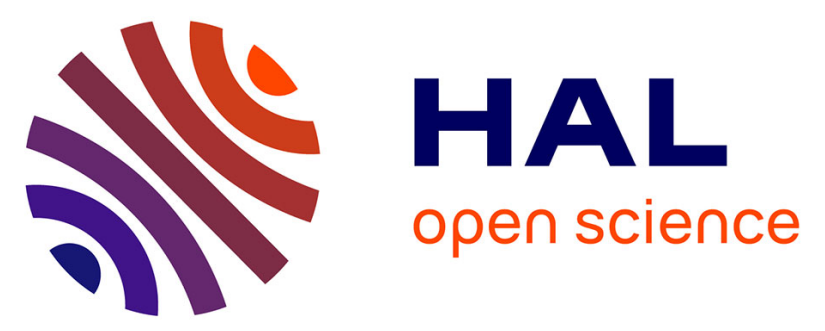

\title{
Seasonal dynamics of extracellular polymeric substances (EPS) in surface sediments of a diatom-dominated intertidal mudflat (Marennes-Oléron, France).
}

Guillaume Pierre, Jean-Michel Zhao, Francis Orvain, Christine Dupuy, Géraldine Klein, Marianne Graber, Thierry Maugard

\section{To cite this version:}

Guillaume Pierre, Jean-Michel Zhao, Francis Orvain, Christine Dupuy, Géraldine Klein, et al.. Seasonal dynamics of extracellular polymeric substances (EPS) in surface sediments of a diatomdominated intertidal mudflat (Marennes-Oléron, France).. Journal of Sea Research (JSR), 2013, 92, pp.26-35. 10.1016/j.seares.2013.07.018 . hal-01070408

\section{HAL Id: hal-01070408 \\ https://hal.science/hal-01070408}

Submitted on 7 Oct 2014

HAL is a multi-disciplinary open access archive for the deposit and dissemination of scientific research documents, whether they are published or not. The documents may come from teaching and research institutions in France or abroad, or from public or private research centers.
L'archive ouverte pluridisciplinaire HAL, est destinée au dépôt et à la diffusion de documents scientifiques de niveau recherche, publiés ou non, émanant des établissements d'enseignement et de recherche français ou étrangers, des laboratoires publics ou privés. 
1 Seasonal dynamics of extracellular polymeric substances (EPS) in surface 2 sediments of a diatom-dominated intertidal mudflat (Marennes-Oléron, 3 France).

4 Guillaume Pierre ${ }^{1,2 *}$, Jean-Michel Zhao ${ }^{2}$, Francis Orvain ${ }^{3}$, Christine Dupuy ${ }^{2}$, $5 \quad$ Marianne Graber ${ }^{2}$, Thierry Maugard ${ }^{2}$

(1) Clermont Université, Université Blaise Pascal, Institut Pascal, UMR 6602 CNRS - Polytech ClermontFerrand, 24 avenue des Landais, BP206, F-63174 Aubière cedex, France

(2) UMR 7266 CNRS - ULR LIENSs. Université de La Rochelle, UFR Sciences, Bâtiment Marie Curie, avenue Michel Crépeau, 17042 La Rochelle, France.

(3) Université de Caen Basse-Normandie, CNRS FRE 3484 BioMEA, esplanade de la Paix, 14032 Caen, France.

\section{Abstract}

Numerous field-based investigations have highlighted that the production of Extracellular Polymeric Substances (EPS) is physico-chemically and ecologically essential for intertidal mudflats. EPS are largely secreted by marine benthic diatoms and their quantity and quality are environmental-dependant. This paper focused on the dynamic pathways, concentration rates and monosaccharides composition of colloidal, bound and residual carbohydrates extracted by using a cationic exchange resin from a diatom-dominated intertidal mudflat (Marennes-Oléron, France) during two different sampling periods: winter (February 2008) and summer (July 2008). A wide range of biotic and abiotic parameters were also studied to better understand the effect of environmental parameters, e.g. chlorophyll $a$, salinity, pore water, emersion time, luminosity, $\mathrm{C}: \mathrm{N}$ ratio or tidal coefficient. Multiple colorimetric assays coupled to gas chromatographic analyses were carried out to perform the biochemical 
characterizations. Firstly, the quantity of carbohydrates produced during winter was more important than during summer. Yet, more proteins were found during summer especially for the colloidal and bound fractions. Further investigations showed that the dynamic pathways were equivalent between winter and summer: bound carbohydrates $(\mathrm{BC})$ quantities increased during the sediment emersion periods on the contrary to colloidal carbohydrates (CC) which tended to drop throughout the emersion time. The quality in monosaccharides was fractiondependant, whatever the season. $\mathrm{CC}$ were always glucose-rich confirming their role of carbon source. BC were mainly composed of rhamnose whose the ratio increased during the emersion period, thus conferring adhesive properties to the extracellular matrix bounding diatoms cells. Residual carbohydrates (RC) were composed of various monosaccharides and a major increase of glucose content was found at the end of emersion, corresponding to intracellular C-storage in prevention to immersion times. Summer-RC were composed of fucose, a monosaccharide specific to these fractions and which was non-present during the winter campaign. Environmental parameters, as salinity, pore water, tidal coefficient could have a significant impact on the concentration rates and pathways of carbohydrates.

Key words: Extracellular polymeric substances (EPS), carbohydrates, diatoms, seasonal impacts, mudflat

\section{Introduction}

Intertidal mudflats are extremely productive areas and may provide up to $50 \%$ of the primary and secondary production of estuaries (Underwood and Kromkamp, 1999), especially due to the formation of diatom-dominated biofilms at their surface (Falciatore and Bowler, 2002). Subject to periodic tidal exposure, the physical and chemical properties of these biofilms change (Christie et al., 2000; de Brouwer and Stal, 2001). Thus, some authors noted that 
variations in sediment dynamics and compositions could result from seasonal fluctuations (Frostick and McCave, 1979), and particularly Extracellular Polymeric Substances (EPS) composing benthic biofilms. Benthic biofilms are composed of water, microalgae, prokaryotes (bacteria, archeae), other eukaryotic microbes, virus and inorganic particles entangled in an EPS matrix (Yallop et al., 1994). This EPS matrix is rich in a wide variety of polysaccharides, proteins, glycoproteins, lipids and nucleic acids (Wingender et al. 1999). Besides, marine diatoms are known to produce various kinds of EPS depending on the environmental conditions and the tidal periods (Underwood et al., 2004). On one hand, colloidal EPS are excreted in the microenvironment of the benthic biofilms (Underwood et al., 1995) and are used by different microorganisms, $e . g$. the glucose-rich exudates consumed by heterotrophic bacteria (van Duyl et al., 1999; Hofmann et al. 2009). On the other hand, bound EPS are secreted as mucilaginous slime coating the cells (Underwood and Paterson, 2003). These EPS play key roles in microbial and physico-chemical defense (Decho, 1990), in the motility of epipelic diatoms (Stal and Défarge, 2005), in cells/cells or cells/substratum adhesion (Wimpenny et al. 2000) and sediment biostabilisation (Spears et al., 2008). Several studies have reported large variability of EPS composition, abundance and properties, thus highlighting the scientific challenge to extract and analyze consistently EPS by biochemical methods (Azerado et al., 2003; de Brouwer and Stal, 2004). In this way, Underwood and Paterson (2003) have pointed the importance of the biochemical methodology to accurately reflect the biological utility or relevance of EPS in benthic biofilms. Recently, an alternative method for in situ EPS extraction and determination (Takahashi et al., 2009), applied during two field studies (Pierre et al., 2010 ; Pierre et al., 2012), has shown the possibility to separate three major classes of EPS through the use of a cationic exchange resin (Fig. 1). Moreover, the use of diluted polar solvents in these works allowed the size separation of EPS: shortchain to long-chain oligosaccharides, i.e. low molecular weight (LMW) compounds and high 
molecular weight (HMW) compounds (Decho, 2000; Bellinger et al., 2005). Such characterization of EPS is a necessary step to determine and understand their roles in benthic biofilms, especially if we focus on the influence of biotic and abiotic parameters.

The goal of this study was to investigate the temporal distribution and compositional changes of EPS, in relation to seasonal dynamics. A challenging aim was also to compile numerous data obtained on the same field to clearly show the impact of seasons on the EPS composition of a microphytobenthic biofilm and, a fortiori, on the trophic involvement of intertidal mudflats. The EPS samples were collected from a diatom-dominated biofilm (MarennesOléron Bay, France) during different ecological periods in the chemistry and biology of tidal flats, i.e. in February 2008 (winter) and July 2008 (summer), when the microphytobenthic biofilm development and its EPS composition are supposed to be drastically dissimilar.

\section{Material and methods}

\subsection{Field sampling}

The sediment samples were collected from Marennes-Oléron Bay (Atlantic Coast of France), during only one week in February 2008 (winter) due to strong field constraints and two weeks in July 2008 (summer) at low tide (Fig. 2). The field sampling was organized as a chessboard where square sampling units ( $2 \mathrm{~m}$-side) separated by alleys ( $2 \mathrm{~m}$ in width) were defined. Every day, three squares were randomly considered for spatial heterogeneity. Sediment samples from each square were collected by using core diameter of $20 \mathrm{~cm}$. Three cores of each selected square were sampled every hour during the tidal periods. For each core, the top $1 \mathrm{~cm}$ was collected three times and pooled. After each sampling, sediment pools were brought back from the field for an immediate EPS extraction on fresh sediments. Biochemical analyses were then performed in triplicate on the colloidal, bound and residual fractions (864 fractions). 


\subsection{Biotic and abiotic measurements}

The chlolophyll $a$ concentration in the sediment was measured using fluorometry method (Lorenzen, 1966). Light was measured using a Li-Cor sensor which was recorded every minute during sampling days. Salinity, pore water, C:N ratio were also followed. Enumeration of bacteria was performed by microscopy, after 4,6-diamidino-2-phenylindole dihydrochloride (DAPI) labeling (x 1000, Axioskop, Zeiss) using the method of Porter and Feig (1980). All missing data were due to experiment constraints.

\subsection{Material}

Solvents, cationic resin (Dowex Marathon C), assay kits, protein (Bovine Serum Albumin, BSA) and carbohydrate standards (dextran, dextran sulftate, glucose, galactose, rhamnose, fucose, fructose, xylose, arabinose, ribose, mannose, myo-inositol, glucuronic and galacturonic acids) were obtained from Sigma-Aldrich. The DB-1701 J and W Scientific column (30 m, $0.32 \mathrm{~mm}, 1 \mu \mathrm{m})$ for Gas Chromatography-Mass Spectrometry analysis (GC/MS) was obtained from Agilent.

\subsection{EPS extraction and fractionation}

The extraction method (Takahashi et al., 2009) was done immediately after sampling and sediment mixing on the field. $20 \mathrm{~mL}$ of fresh mudflat was continuously mixed with $20 \mathrm{~mL}$ of Artificial Sea Water (ASW 30 Practical Salinity Units) during $1 \mathrm{~h}$ in darkness at $4{ }^{\circ} \mathrm{C}$ and then centrifuged at $3500 \mathrm{~g}$ and $4{ }^{\circ} \mathrm{C}$ for $10 \mathrm{~min}$. The supernatant containing colloidal EPS was collected and stored at $4{ }^{\circ} \mathrm{C} .20 \mathrm{~mL}$ of $\mathrm{ASW}$ and $1 \mathrm{~g}$ of activated Dowex Marathon C, previously prepared in Phosphate Buffer Saline for $1 \mathrm{~h}$ in the dark, was added to the sediment pellet. The samples were mixed gently at $4{ }^{\circ} \mathrm{C}$ for $1 \mathrm{~h}$ in the dark and then centrifuged at 3500 $\mathrm{g}$ and $4{ }^{\circ} \mathrm{C}$ for $10 \mathrm{~min}$. A supernatant containing the bound EPS and a cap containing intracellular and residual polymers were obtained. The cap was then frozen. The residual 
polymers were extracted from the frozen sediment samples by sonication at $100 \mathrm{~W}$ for 3 min on ice after resuspension in $20 \mathrm{~mL}$ in ASW. For each fraction (colloidal, bound and residual polymers), absolute ethanol at $-20{ }^{\circ} \mathrm{C}$ was added to the sample to obtain a final ethanol concentration of $75 \%(\mathrm{v} / \mathrm{v})$. The solution was gently mixed and stored overnight at $-20{ }^{\circ} \mathrm{C}$. The solution was then centrifuged at $3500 \mathrm{~g}$ and $4{ }^{\circ} \mathrm{C}$ for $15 \mathrm{~min}$ to obtain a supernatant (LMW fraction) and a precipitate pellet (HMW fraction). Finally, the fractions were dried under air flow and stored at $-20{ }^{\circ} \mathrm{C}$.

\subsection{Carbohydrate, uronic acid and protein analysis}

Total sugar content was determined by the phenol-sulfuric acid assay, using glucose as a standard (Dubois et al., 1956). Total sugar amounts for the fractions were measured and normalized to chlorophyll $a(\operatorname{chl} a)$, thus allowing the overestimation of diatom EPS, comparing to other EPS sources (Underwood and Paterson, 2003). Uronic acid content was determined using the meta-hydroxydiphenyl method (MHDP), with galacturonic and glucuronic as standards (Blumenkrantz and Asboe-Hansen, 1973; Filisetti-Cozzi and Carpita, 1991). Protein content was determined by the bicinchoninic acid (BCA) method, using bovine serum albumin (BSA) as a standard (Smith et al., 1985).

2.6. Gas Chromatography coupled to Mass Spectrometry (GC/MS) to characterize the carbohydrate of EPS fractions

EPS fractions were solubilized in $5 \mathrm{~mL}$ of ultrapure water, dialyzed (6-8 KDa) and freezedried. EPS were then dissolved in $2 \mathrm{M} \mathrm{HCl}$ at $50 \mathrm{mg} / \mathrm{mL}$ and heated at $90{ }^{\circ} \mathrm{C}$ for $4 \mathrm{~h}$. The preparation was then freeze-dried and stored at $-20{ }^{\circ} \mathrm{C}$. Analyses were carried out by GC/MS using a Varian CP-3800 GC/Varian Saturn 2000. $400 \mu \mathrm{L}$ of pyridine and $400 \mu \mathrm{L}$ of BSTFA: TMCS (99: 1) was added to $2 \mathrm{mg}$ of purified monosaccharides. The solution was mixed for 2 $\mathrm{h}$ at room temperature, then injected into a DB-1701 J\&W Scientific column $(30 \mathrm{~m}, 0.32 \mathrm{~mm}$, 
$1 \mu \mathrm{m})$ at a flow of $1 \mathrm{~mL} / \mathrm{min}$. The helium pressure was 8.8 psi. The temperature of the injector was set at $250{ }^{\circ} \mathrm{C}$. The rise in temperature in the oven was programmed for a first step at $150{ }^{\circ} \mathrm{C}$ for $0 \mathrm{~min}$, then an increment of $10{ }^{\circ} \mathrm{C} / \mathrm{min}$ up to $200{ }^{\circ} \mathrm{C}$ with a final step at $200{ }^{\circ} \mathrm{C}$ for $35 \mathrm{~min}$. The ionization was performed by Electronic Impact (EI, $70 \mathrm{eV}$ ), the trap temperature was set at $150{ }^{\circ} \mathrm{C}$ and the target ion was fixed at $40-650 \mathrm{~m} / \mathrm{z}$.

\subsection{Statistical analysis}

All statistical analyses were run using the statistical software XLStat (Addinsoft). One-way ANOVA was used to analyze changes in carbohydrate and uronic acid amounts among abiotic parameters for each day (sampling location and emersion time). Data transformations (root) were performed to check application conditions (normality) each time it was required. Post hoc procedures (Tukey test) were performed to analyze pairwise differences. $t$ and $Z$-tests were conducted to determine significant differences between values of variables at the beginning and at the end of the emerged period. Pearson correlation tests were done with the complete data set to investigate the relationships between the different EPS fractions with biotic (bacterial abundance, $\mathrm{Chl} a$ ) and abiotic (luminosity, salinity) parameters. Principal component analyses were used to highlight and group fractions with closed monosaccharides distributions.

\subsection{Abbreviations and nomenclature}

In accordance with the literature (Underwood et al., 2010), the term "carbohydrates" refers to the total sugars (neutral and acidic sugars) determined by Dubois assays and GC/MS. The term "uronic acids" corresponds only to the uronic assays clearly measured by the BCA method or GC/MS analyses. Concerning the abbreviations, W and S correspond to winter and summer, the two sampling periods. LMW and HMW refer to the size of the carbohydrates: low molecular weight and high molecular weight. $\mathrm{CC}, \mathrm{BC}$ and $\mathrm{RC}$ refer to the carbohydrates 
extracted from the three main fractions: colloidal carbohydrates (CC) are water-extractable, bound carbohydrates (BC) are obtained by using Dowex Marathon $\mathrm{C}$, and residual carbohydrates (RC) correspond to the fractions rich in intracellular carbohydrates and refractory EPS.

\section{Results and discussion}

3.1. Relationships between EPS and environmental parameters: a seasonal heterogeneity?

The total carbohydrate quantities and the contribution of neutral carbohydrates, uronic acid and proteins were determined for the three main EPS fractions extracted in winter and summer (Fig. 3). At this step, it is noteworthy that the sugar amounts were normalized to Chl $a$ in order to overestimate diatom EPS production, comparedto other EPS sources (Haubois et al., 2005). In average and regardless the emersion time, more colloidal carbohydrates were extracted from the sediment in winter $\left(5.28 \mu \mathrm{g} . \mu \mathrm{g} \mathrm{chl} a^{-1}\right)$ than summer $\left(2.04 \mu \mathrm{g} . \mu \mathrm{g} \mathrm{chl} a^{-1}\right)$. The same observations were done for the bound and residual carbohydrates since 2.5 times more carbohydrates were found in the winter samples (Fig. 3A). Concerning the relative contribution of neutral and acidic sugars, the results showed that neutral sugars were the main component of the fractions both in summer and winter although the ratios varied during these two periods. For the colloidal and bound fractions, the neutral sugar ratios dropped from $78 \%$ to $61 \%$ and $87 \%$ to $63 \%$ respectively (relative $\% \mathrm{w} / \mathrm{w}$ ) due to the presence of proteins in the fractions extracted in summer.

However, if we focus only on the carbohydrate part, no significant change $(p<0.01)$ was observed for the neutral sugar ratios. Previous papers noted that variations in sediment dynamics resulted from seasonal changes in biological influences (Frostick and McCave, 1979), EPS quality and quantity being excellent indicators to measure the impact of these modifications. In this way, correlations were found between the level of EPS and the diatom 
biomass in the sediment, i.e. EPS quantities reduced when the diatom biomass decreased (Staats et al., 2001). Ambient light climate play an essential role on the photosynthetic power of epipelic diatoms, which move up to the sediment (Serôdio et al., 1997). Microphytobenthic biofilms can have high rates of photosynthesis and a large part of the photo-assimilated carbon is excreted into the environment as exopolymers (Underwood and Paterson, 2003). During our sampling periods, the luminosity was around $1600 \pm 400 \mu \mathrm{mol}$ photons. $\mathrm{m}^{-2} . \mathrm{s}^{-1}$ in summer and $440 \pm 250 \mu \mathrm{mol}$ photons. $\mathrm{m}^{-2} \cdot \mathrm{s}^{-1}$ in winter. The level of chl $a$ measured on the sediment was significantly lower $(\mathrm{p}<0.01)$ in summer $\left(8.1 \pm 1.2 \mu \mathrm{g} . \mathrm{g}\right.$ dry sediment $\left.{ }^{-1}\right)$ than in winter $\left(20.2 \pm 0.9 \mu \mathrm{g} . \mathrm{g}\right.$ dry sediment $\left.{ }^{-1}\right)$. This difference was attributed to the intense level of grazing by Peringia ulvae whose the density was higher in summer (17.2 ind. $\left.\mathrm{m}^{-2} \pm 7.08\right)$ than in winter $\left(5.77\right.$ ind. $\left.\mathrm{m}^{-2} \pm 2.99\right)$. Moreover, the classical normalization with chl $a$ enhanced the gap between the values in summer and winter. Besides, intertidal mudflats are living areas whose the primary trophic production is non-negligible. Indeed, diatoms and their EPS production are responsible for 40 to $50 \%$ of the total global primary production in marine systems (Medlin, 2002). So, biota living in the intertidal zone are adapted to use EPS as food or as protection against environmental dynamics which dominate tidal flats (Widdows and Brinsley, 2002). During summer periods, consumers of EPS (carbon source) are much more active and directly responsible in a drop of sediment stability (Andersen, 2001). This greater summer consumption could also explain the differences between the amounts of carbohydrates measured in summer and winter.

Thirdly, the amounts of proteins detected during summer were interesting because specific of this period (Fig.3, B). Yet, proteins were also found in colloidal and bound fractions collected in summer. During summer, pore water in the sediment was significantly lower than in winter $(\mathrm{p}<0.05)$ and positive correlations were found with S-LMW CC and S-LMW BC (Table 1, p $<0.05$ ). Some authors have suggested that EPS (carbohydrates and proteins) could protect 
microphytobenthos from high desiccation levels and salinity (Spears et al., 2008). Thus, we concluded that the presence of proteins combined to specific carbohydrates during summer could be a response to desiccation stress, explaining the positive correlations found (Table 1). These fractions could be correlated to osmoregulatory and hydratation properties to fight against extensive salinity. Besides, proteins can also be used as additional C-storage which can explain their presence in residual fractions, composed of intracellular (chrysolaminaran) and refractory EPS.

A number of authors have pointed at the rapid changes, in order to hour, which occur at the surface sediments during periodic tidal exposures but the patterns varied even if colloidal carbohydrates are often involved (Taylor and Paterson, 1998; Christie et al., 2000, Hofmann et al. 2009, Pierre et al. 2012). The fate of colloidal and bound carbohydrate amounts between the beginning and the end of the emersion periods during winter and summer was then investigated in this work (Fig. 4). LMW colloidal carbohydrate amounts tended to decrease during the emersion period. This drop observed in winter was not significant $(\mathrm{p}<0.05)$ but significantly visible in summer $(\mathrm{p}<0.01)$. Besides, HMW colloidal carbohydrate amounts remained stable all over the emersion time, in winter or summer. These results were contradictory to other works which reported an increase of colloidal EPS in the early part of the tidal exposure and near to the end of the emersion (Taylor, 1998). Nevertheless, Underwood and Paterson (2003) nuanced these results and argued that the evolution of colloidal EPS during the emersion period was often misinterpreted due to the extraction techniques used. In this way, previous studiesdid not specifically work on colloidal EPS but on fractions containing a part of bound and residual polymers. The Dowex extraction that we performed allowed a fine separation between true colloidal and bound EPS surrounding diatom cells and/or entangled in the EPS matrix (Fig. 1). We already demonstrated that the use of this procedure in situ averted mixing a part of colloidal EPS with LMW bound EPS 
(Pierre et al., 2012). It can be estimated that the levels and production patterns of colloidal EPS that we found in the present study were then closer to their function(s) and fate. Thus, many authors highlighted that colloidal EPS were C-sources in the trophic network of tidal mudflats, especially for heterotrophic bacteria and other micro-consumers (van Duyl et al., 1999; Hanlon et al. 2006; Pierre et al. 2012).

On the other hand, the amounts of bound carbohydrates increased all over the tidal exposure. Even if this observation was not significant for W-LMW BC due to a lack of experimental values $(p<0.05)$, significant increases were observed in summer $(p<0.01)$. Owing to the use of the Dowex procedure, it was possible to distinguish the fate of true colloidal carbohydrates whose the amounts dropped and bound carbohydrates whose the concentrations increased during the emerged period. A part of this result was already observed (Pierre et al., 2012), leaving us to suggest that bound fractions could be involved in the formation and adhesion of the microphytobenthic biofilm. The role of microphytobenthos as sediment stabilizers was well documented (Underwood and Paterson, 1993; Paterson and Black, 1999, Thornton et al., 2002; Widdows and Brinsley, 2002; Spears et al., 2008) and a reduction in erosion state was already correlated with increasing of carbohydrates concentrations (Sutherland et al., 1998). Numerous authors suspected the role of colloidal EPS in general on the sediment dynamics but not of a very specific and separate part of these exopolymers. Nevertheless, recent works brought colloidal and especially bound EPS to the fore, whose the production could be lightdependant (Giroldo et al., 2003; Underwood and Paterson, 2003; Hofmann et al. 2009; Pierre et al., 2011). Anyway, we noted that no light-dependant production was found for the bound fractions on the contrary to colloidal fractions whose the production was tidal coefficientdependant (Table 1, $\mathrm{p}<0.05$ ).

Numerous authors try to understand how the composition and dynamic of EPS produced by benthic diatoms change depending on environmental conditions (Underwood and Paterson, 
2003). Thus, biochemical nature, production pathways, role and fate of EPS in intertidal ecosystems are widely studied. In general, all authors point that chemical and physical properties of EPS produced in situ vary significantly in response to biotic and abiotic parameters. That is why important abiotic and biotic parameters were followed in this study, as chl $a$, light, salinity, pore water, bacterial abundance, tidal coefficient, $\mathrm{C}: \mathrm{N}$ ratio, in view of understanding their involvement in EPS dynamic productions. We previously showed that salinity, pore water, light and chl $a$ have to be considered when the seasonal dynamics of EPS are studied. But it was also interesting to note that tidal coefficients could have a significant impact (Table 1) which was logical since tidal coefficients influence the degree of periodic tidal emersions and the light degree. Besides, no significant patterns were found for bacterial abundance or $\mathrm{C}: \mathrm{N}$ ratios. It was not possible to correlate $\mathrm{C}: \mathrm{N}$ ratios with the presence of marine bacteria/microalgae, terrestrial or degraded organic matter.

\subsection{Monosaccharide composition of EPS: roles and functions of the different fractions}

Monosaccharide composition of EPS was investigated for colloidal, bound and residual fractions extracted in winter and summer (Fig. 5). The monosaccharide composition was heterogeneous depending on the concerned fractions and the low standard deviations $(<5 \%)$ indicated that the types and quantities of EPS were finely controlled during the short-term emerged periods. Colloidal carbohydrates were rich in glucose (> 50\%), xylose, galacturonic acid and inositol, regardless the sampling period. Indeed, colloidal carbohydrates are known as carbon trophic sources due to their high quantity of glucose (Abdullahi et al., 2006; Hofmann et al. 2009). Nevertheless, we noted that the colloidal carbohydrates collected in summer were richer in glucose than in winter $(+4 \%, p$ value $[5 \%]=0.003)$. The same observation was also done for bound and residual fractions (+ 40 and $45 \%$ respectively). On the one hand, the high glucose ratio in residual fractions (22 to $42 \%$ ) was not surprising since these samples correspond essentially to intracellular carbohydrates. The majority of the 
glucosyl units found in these fractions are components of storage polymers as chrysolaminaran (Underwood and Paterson, 2003). On the other hand, it seemed important to focus on the increase of glucose content in colloidal and bound fractions during summer. We suggested that the phenomenon was a seasonal response to environmental needs due to Cconsumers, as nematods, hydrobia or herbivorous zooplankton, which are more abundant and more active in summer. Thus, colloidal carbohydrates dropped during the emersion time (Fig. 4) but glucose content were higher (Fig. 5). It is therefore possible that carbohydrate EPS are selectively used by heterotrophic bacteria depending on season. In this way, bacteria could use the different monosaccharide as substrate but with different degrees of induction. Besides, the ratios of structural hexoses (xylose and mannose) and uronic acids (galacturonic acids) were lower in summer for colloidal and bound fractions.

Rhamnose was the monosaccharide widely found in LMW (> $25 \%$ ) and HMW (18 to $34 \%$ ) bound carbohydrates in winter and summer. The high levels of deoxy sugars in this fraction were already observed in winter on the same sampling site (Pierre et al., 2011) and other studies (Hanlon et al., 2006). Owing to their surface-active properties, deoxy sugars can promote the biostabilisation of sediments (Zhou et al, 1998; Giroldo et al, 2003) by facilitating the coagulation of particles and macromolecules (Khodse et al., 2007). Rhamnose could also play a role of biochemical sensor in microphytobenthic biofilms as a target of proteins involved in cell-cell transmission signals. However, the level of rhamnose was lower in summer for the HMW bound fractions, i.e. for carbohydrates closely attached to diatom cells. This observation suggested a potential lower biostabilisation of the sediment in summer (LMW BC: $25.6 \%$, HMW BC: $18 \%$ ).

Fucose, a monosaccharide missing during winter samplings, was found in residual fractions $(10 \%)$ collected in summer. We previously attributed the lack of fucose to the physiological state of the growing biofilm studied in winter (Pierre et al., 2012). During summer, colloidal 
and bound fractions did not contain fucose, in contrary to many works (Abdullahi et al., 2006; Hanlon et al., 2006; Hofmann et al., 2009; Takahashi et al., 2009). It is relevant to highlight that fucose is a monosaccharide involved in the metabolic pathways occurring during the degradation of $\beta$-1,3-glucan storage in diatom cells (Granum, 2002), which could explain its unique presence in residual fractions.

In the same way, another surprising sugar, inositol, was also found in the different samples and particularly in colloidal fractions (7 to $17 \%$ ). As we already reported (Pierre et al., 2012), this monosaccharide could be a growth factor for heterotrophic microorganisms involved in the microphytobenthic biofilm formation and synergistic relationships between benthic diatoms and bacteria (Lubarsky et al., 2010). Moreover, its production seemed to be nonseasonal dependant $(-5 \%)$.

A principal component analysis (ACP) along dominant sugar vectors was performed to clearly identify the differences in monosaccharide distributions of the EPS fractions (Fig. 6). Three distinct clusters were highlighted by ACP (C1 to C3). C1 was a cluster constituted of carbohydrates rich in glucose and inositol. Colloidal carbohydrates were sorted in C1. However, a significant seasonal difference was found between the monosaccharide distribution of W-LMW CC and S-LMW CC. Light and pore water could play a significant role in this dissimilarity (Table $1, \mathrm{p}<0.05$ ). So, the monosaccharide distribution of LMW CC could be seasonal dependant (no cluster). These fractions are extremely labile and can be selectively consumed by heterotrophic bacteria. Cluster 2 represented fractions rich in rhamnose, xylose and galacturonic acid. Bound fractions, excepting S-HMW BC, belonged to C2. Previously, we noted that the rhamnose content was lower in S-HMW BC and we suggested that this ratio could play a major impact on sediment biostabilisation. 
It was noteworthy that residual carbohydrates were rich in glucose. However, galacturonic acid, galactose, fucose and mannose were ACP sugar vectors to take into account to sort these fractions (C3). Anyway, the results highlighted a strong heterogeneity of carbohydrate distributions in residual fractions which could be further investigated.

\subsection{In situ modification of monosaccharides distribution: specific pathways?}

The mechanisms allowing diatoms to rapidly change the EPS types being produced are not well understood (Underwood and Paterson, 2003; Hofmann et al., 2009). Moreover, this is the selective consumption of carbohydrate EPS by heterotrophic bacteria which seems to play the major role in these EPS changes (Giroldo et al., 2003). Previously, we showed that four major monosaccharides (glucose, xylose, galacturonic acid, rhamnose) characterized the different

352 fractions with some ratios above $20 \%$. Fucose was only found during summer specifically in residual fractions. Moreover, these monosaccharides were representative sugars vectors in ACP analyses to identify clusters. That is why the standing stocks of these five monosaccharides were followed during the emerged periods in order to highlight possible specific pathways of selective consumption (Fig. 7). The first important observation to note

357 was that the same monosaccharide distribution patterns were observed during winter and 358 summer. Combined to our previous conclusions, this major result indicated that the 359 distribution of monosaccharides in the fractions seemed to follow the same process regardless 360 the season and also that the carbohydrate production, in term of amounts, could vary in 361 response to environmental parameters (cf. part 3.2.). Bacterial interactions, adhesion and 362 biofilm formation, protection against salinity or migration into the sediment could be ecological and physico-chemical phenomena involving EPS changes.

364 In details, the results showed that all over the emersion periods, glucose amounts stayed stable 365 whatever a possible consumption of colloidal carbohydrates by heterotrophic bacteria. 
Galacturonic acid amounts dropped and rhamnose concentrations slightly increased for colloidal fractions extracted in winter and summer. The evolution in the galacturonic acid distribution was interesting and suggested that colloidal fractions were not only used as Csources. Uronic acids are involved in several marine environmental processes including the production of macroaggregates, microbial adhesion and biofilm formation, binding of extracellular enzymes or ion sequestration (Decho, 1990; Sutherland, 2001; Bhaskar et al., 2005). This drop of uronic acids amounts could have an impact on the biofilm community, maybe by protecting diatoms from extreme salinity conditions.

If we focus on bound fractions, rhamnose amounts increased during the emersion time. We extensively discussed about the potential role of deoxy sugars in part 3.2 (cell-cell interactions) and this observation seemed to confirm the involvement of rhamnose in adhesion phenomena or in the motility of diatom cells. Finally, residual fractions, rich in intracellular carbohydrates and refractory EPS were very complex in accordance with the literature. The important point to highlight was the slight drop of glucose amounts during the first hours of emersion, followed by a large increase of glucose ratios. This result could be due to the use of C-storage during the emerged period (metabolism) then to a drastic storing of carbon to survive during periods of darkness (Hanlon, 2006).

\section{Conclusion}

Based on extensive data set (> 800 fractions), this paper focused on the seasonal dynamics of EPS and extensively carbohydrates produced on an intertidal mudflat during two different sampling periods (winter and summer). Firstly, colloidal carbohydrates, well known as Csources for heterotrophic bacteria and other C-consumers, were steadily produced suggesting that an ecological equilibrium maybe existed between carbon production and consumption. The increase of bound carbohydrate levels during emersion times could show their 
involvement in adhesion/cohesive properties and/or in the locomotive properties of diatom cells which have to migrate back into the sediment at the end of emersion time. These dynamic pathways were identical between winter and summer, even if the data numbers allowed us to significantly confirm this hypothesis only for summer. The presence of proteins during summer was correlated to an additional C-storing for diatoms cells (residual fractions) and to a potential protection against high desiccation and salinity degrees. A number of abiotic/biotic parameters seemed to have impact on EPS dynamics and production as salinity, pore water, light or tidal coefficient. At last, GC/MS analyses showed that colloidal carbohydrates were glucose-rich, bound carbohydrates were significantly composed of rhamnose and residual fractions presented a wide variety of monosaccharides. All the fractions were richer in glucose during summer than winter, maybe to response to greater trophic needs. ACP analyses allowed refining the results and highlighted that colloidal carbohydrates formed a first cluster (glc, ino). Cluster 2 (xyl, rham) was constituted of bound carbohydrates and cluster 3 (fuc, gal. acid, gal, man) of residual carbohydrates. The evolution of five representative monosaccharides (glc, gal. acid, xyl, rham, fuc) was also followed in function of the tidal emersion periods and the results showed again that the distribution pathways did not change in winter or summer in contrary to monosaccharide amounts. We noted that the levels of galacturonic acid varied for colloidal and bound fractions, which could have an effect on binding forces, protection (via ion sequestration for instance) and cell-cell interactions in microphytobenthic biofilms. Besides, C-storage consumption and C-storing (glc, fuc, man) were observed in residual fractions during the emerged periods. To conclude, many results were consistent with the literature and additional information were obtained concerning the influence of seasonal parameters on EPS productions and dynamics. It should be interesting to check whether these conclusions could be observed on a much larger data set, specifically targeting light, salinity and pore water, tidal coefficient as major parameters. 


\section{Acknowledgements}

416

417 de Projets Etat-Région "Littoral" and the Centre National de la Recherche Scientifique. The

418 field sampling was supported by the French ANR (National Research Agency) through the

419 VASIREMI project "Trophic significance of microbial biofilms in tidal flats" (contract ANR-

420 06-BLAN-0393-01).

421

422

423

424

425

426

427

428

429

430

431

432

433

434

435

\section{References}

Abdullahi, A.S., Underwood, G.J.C, Gretz, M.R., 2006. Extracellular matrix assembly in diatoms (Bacillariophyceae). V. Environmental effects on polysaccharide synthesis in the model diatom, Phaeodactylum tricornutum. J. Phycol. 42, 363-378.

Andersen, T.J., 2001. Seasonal variation in erodability of two temperate microtidal mudflats. Est. Coast. Shelf Sci. 49, 99-111.

Azerado, J., Henriques, M., Sillankorva, S., Oliveira, R., 2003. Extraction of exopolymers from biofilm: the protective effect of glutaraldehyde. Wat. Sci. Technol. 47, 175-179.

Bellinger, B.J., Abdullahi, A.S., Gretz, M.R., Underwood, G.J.C., 2005. Biofilm polymers: relationship between carbohydrate biopolymers from estuarine mudflats and unialgal cultures of benthic diatoms. Aquat. Microb. Ecol. 38, 169-180.

Bhaskar, P.V., Bhosle, N.B., 2005. Microbial extracellular polymeric substances in marine biogeochemical processes. Curr. Sci. $88,45-53$.

Blumenkrantz, N., Asboe-Hansen, G., 1973. New method for quantitative determination of uronic acids. Anal. Biochem. 54, 484-489. 
Christie, M.C., Dyer, K.R., Blanchard, G., Cramp, A., Mitchener, H.J., Paterson, D.M., 2000. Temporal and spatial distributions of moisture and organic content across a macro-tidal mudflat. Cont. Shelf Res. 20, 1219-1242.

de Brouwer, J.F.C, Stal, L.J., 2001. Short-term dynamics in microphytobenthos distribution and associated extracellular carbohydrates in surface sediments of an intertidal mudflat. Mar. Ecol. Prog. Ser. 218, 33-44.

de Brouwer, J.F.C, Stal, L.J., 2004. Does warm-water extraction of benthic diatoms yield extracellular polymeric substances or does it extract intracellular chrysolaminaran? Eur. J. Phycol. 39, 129-131.

Decho, A.W., 1990. Microbial exopolymer secretions in ocean environment: their role(s) in food webs and marine processes. Oceanogr. Mar. Biol. Ann. Rev. 28, 73-153.

Decho, A.W., 2000. Microbial biofilms intertidal systems: an overview. Cont. Shelf Res. 20, 1257-1274.

Dubois, M., Gilles, K.A., Hamilton, J.K., Rebers, P.A., Smith, F., 1956. Colorimetric method ofr determination of sugars and related substances. Anal. Chem. 28, 350-356.

Falciatore, A., Bowler, C., 2002. Revealing the molecular secrets of marine diatoms. Annu. Rev. Plant Biol. 53, 109-130.

Filisetti-Cozzi, T.M., Carpita, N.C., 1991. Measurement of uronic acids without interference from neutral sugars. Anal. Biochem. 197, 157-162.

Frostick, L.E., McCave, I.N., 1979. Seasonal shifts of sediment within an estuary mediated by algal growth. Estuar. Coast Mar. Sci. 9, 569-576. 
457 Giroldo, D., Vieira, A.A.H., Paulsen, B.S., 2003. Relative increase of deoxy sugars during microbial degradation of an extracellular polysaccharide released by a tropical freshwater Thalassiosira sp. (Bacillariophyceae). J. Bacteriol. 189, 7945-7947.

Granum, E., Myklestad, S.M., 2001. Mobilization of $\beta$-1,3-glucan and biosynthesis of amino acids induced by $\mathrm{NH}^{4+}$ addition to $\mathrm{N}$-limited cells of the marine diatom Skeletonema costatum (Bacillariophyceae). J. Phycol. 37, 772-782.

Haubois, A.G., Sylvestre, F., Guarini, J.M., Richard, P., Blanchard G., 2005. Spatio-temporal structure of the epipelic diatom assemblage from an intertidal mudflat in Marenne-Oléron Bay, France. Estuar. Coast. Shelf Sci. 64, 385-394.

Hanlon, A.R.M, Belinger, B., Haynes, K., Xiao, G., Hofmann, T.A., Gretz, M.R., Ball, A.S., Osborn, M., Underwood, G.J.C, 2006. Dynamics of extracellular polymeric substances (EPS) production and loss in an estuarine, diatom-dominated, microbial biofilm over a tidal emersion-immersion period. Limno. Oceanogr. 51, 79-93.

Hofmann, T., Hanlon, A.R.M, Taylor, J.D., Ball, A.S., Osborn, A.M., Underwood, G.J.C., 2009. Dynamics and compositional changes in extracellular carbohydrates in estuarine sediments during degradation. Mar. Ecol. Prog. Ser. 379, 45-58.

Khodse, V.B., Fernandes, L., Gopalkrishna, V.V., Bhosle, N.B., Fernandes, S.G., Matondkar, S.G.P., Bhushan, R., 2007. Mar. Chem. 103, 327-346.

Lorenzen, S., 1966. A method for the continous measurement of in vivo chlorophyll concentration. Deep Sea Res. 13, 223-227.

Lubarsky, H.V., Hubas, C., Chocholek, M., Larson, F., Manz, W., Paterson, D.M., Gerbersdorf, S.U., 2010. The stabilization potential of individual and mixed assemblages of natural bacteria and microalgae. PLoS ONE. 5, e13794. 
480

481

482

483

484

485

486

487

488

489

490

491

492

493

494

495

496

497

498

499

500

501

Medlin, L.K., 2002. Why silica or better yet why not silica? Speculations as to why the diatoms utilize silica as their cell wall material. Diatom Res. 17, 453-459.

Paterson, D.M., Black, K.S., 1999. Water flow, sediment dynamics and benthic biology. Adv. Ecol. Res. 29, 155-193.

Pierre, G., Graber, M., Orvain, F., Dupuy, C., Maugard, T., 2010. Biochemical characterization of extracelular polymeric substances extracted from an intertidal mudflat using a cation exchange resin. Biochem. Syst. Ecol. 38, 917-923.

Pierre, G., Graber, M., Rafiliposon B.A., Dupuy, C., Orvain, F., de Crignis, M., Maugard, T., 2012. Biochemical composition and changes of extracellular polysaccharides (ECPS) produced during microphytobenthic biofilm development (Marennes-Oléron, France). Microb. Ecol. 63, 157-169.

Porter, K.G., Feig, Y.S., 1980. The use of DAPI for identifying and counting aquatic microflora. Limnol. Oceanogr. 25, 943-948.

Serôdio, J., da Silva, J.M., Catarino, F., 1997. Non-destructive tracing of migratory rhythms of intertidal benthic microalgae using in vivo chlorophyll $a$ fluorescence. J. Phycol. 33, 542553.

Smith, P.K., Krohn, R.I., Hermanson, G.T., Mallia, A.K., Gartner, F.H., Provenzano, M.D., Fujimoto, E.K., Goeke, N.M., Olson, B.J., Klenk, D.C., 1987. Measurement of protein using bicinchoninic acid. Anal. Biochem. 150, 76-85.

Spears, B.M., Saunders, J.E., Davidson, I., Paterson, D.M., 2008. Microalgal sediment biostabilisation along a salinity gradient in the Eden Estuary, Scotland: unraveling a paradox. Mar. Freshwat. Res. 59, 313-321. 
Staats, N., de Deckere, E.M.G.T., de Winder, B., Stal, L.J., 2001. Spatial patterns of benthic diatoms, carbohydrates and mud on a tidal flat in the Ems-Dollard estuary. Hydrobiol. 448, $107-115$.

Stal, L.J., Défarge, C., 2005. Structure and dynamics of exopolymers in an intertidal diatom biofilm. Geomicrob. J. 22, 341-352.

Sutherland, T.F., Grant, J., Amos, C.L., 1998. The effect of carbohydrate production by the diatom Nitzschia curvilineata on the erodability of sediment. Limnol. Oceanogr. 43, 65-72.

Sutherland, I.W., 2001. Biofilm exopolysaccharides: a strong and sticky framework. Microbiol. 147, 3-9.

Takahashi, E., Ledauphin, J., Goux, D., Orvain, F., 2009. Optimizing extraction of extracellular polymeric substances (EPS) from benthic diatoms: comparison of the efficiency of six EPS extraction methods. Mar. Freshwater. Res. 60, 1201-1210.

Taylor, I, Paterson, D.M., 1998. Microspatial variation in carbohydrate concentrations with depth in the upper millimeters of intertidal cohesive sediments. Est. Coast. Shelf Sci. 46, 359370.

Thornton, D.C.O., Dong, L.F., Underwood, G.J.C., Newell, D.B., 2002. Factors affecting microphytobenthic biomass, species composition and production in the Colne Estuary (UK). Aquat. Microb. Ecol. 27, 285-300.

Underwood, G.J.C, Paterson, D.M., 1993. Seasonal changes in diatom biomass, sediment stability and biogenic stabilization in the Severn estuary. J. Mar. Biol. Ass. 73, 871-887.

Underwood, G.J.C., Paterson, D.M., Parkes, R.J., 1995. The measurement of microbial carbohydrate exopolymères from intertidal sediments. Limnol. Oceano. 40, 1243-1253. 
Underwood, G.J.C, Kromkamp, J., 1999. Primary production by phytoplankton and microphytobenthos in estuaries. Adv. Ecol. Res. 29, 93-153.

Underwood, GJ.C., Paterson, D.M., 2003. The importance of extracellular carbohydrate production by marine epipelic diatoms. Adv. Bot. Res. 40, 184-240.

Underwood, G.J.C, Boulcott, M., Raines, C.A., 2004. Environmental effects on exopolymeric production by marine benthic diatoms: dynamics, changes in composition, and pathways of production. J. Phycol. 40, 293-304.

Underwood, G.J.C., Fietz, S., Papadimitriou, S., Thomas, D.N., Dieckmann, G.S., 2010. Distribution and composition of dissolved extracellular polymeric substances (EPS) in Antarctic sea ice. Mar. Ecol. Prog. Ser. 404, 1-19.

van Duyl, F.C., de Winder, B., Kop, A.J., Wollenzien, U., 1999. Tidal coupling between carbohydrate concentrations and bacterial activities in diatom-inhabited intertidal mudflats. Mar. Ecol. Prog. Ser. 191, 19-32.

Widdows, J., Brinsley, M., 2002. Impact of biotic and abiotic processes on sediment dynamics and the consequences to the structure and functioning of the intertidal zone. J. Sea Res. 48, 143-156.

Wimpenny, J., Manz, W., Szewzyk, U., 2000. Heterogeneity in biofilms. FEMS Microbiol. Rev. 24, 661-671.

Wingender, J., Neu, T.R., Flemming, H.C., 1999. What are bacterial extracellular polymeric substances?, in: Wingender, J., Neu, T.R., Stadler, P. (Eds.), Microbial extracellular polymeric substances: characterization, structure and function. Springer-Verlag, Berlin, pp. 115. 
546 Yallop, M.L., Paterson, D.M., Wellsbury, P., 2000. Inter-relationships between rates of

547 microbial production, exopolymer production, microbial biomass and sediment stability in 548 biofilms of intertidal sediments. Microb. Ecol. 39, 116-127.

549 Zhou, J., Mopper, K., Passow, U., 1998. The role of surface-active carbohydrates in the 550 formation of transparent exopolymer particles by bubble adsorption of seawater. Limnol. 551 Oceanogr. 43, 1860-1871.

552 
553 Table 1. Matrix of Pearson's correlation coefficients between carbohydrate contents of the

554 different fractions (LMW/HMW: low and high molecular weight, CC: colloidal 555 carbohydrates, BC: bound carbohydrates, RC: residual carbohydrates) and biotic/abiotic 556 parameters measured on the sediment and during the two sampling periods (W: winter, S: 557 summer). Values of $\mathrm{r}$ significant at $* \mathrm{p}<0.05, * * \mathrm{p}<0.01$ and $* * * \mathrm{p}<0.001$

Figure 1. Location hypothesis of the different EPS fractions collected by the Dowex method, adapted from the model of Underwood \& Paterson (2003).

Figure 2. Location of the study area (Brouage mudflat, France) where samples of surficial intertidal sediment were collected.

Figure 3. Total carbohydrate quantities $\left(\mu \mathrm{g} \cdot \mu \mathrm{g}\right.$ chlo $\left.a^{-1}\right)$ and relative contribution $(\% \mathrm{w} / \mathrm{w})$ of neutral carbohydrates (light grey), uronic acid (dark grey) and proteins (grey) for each EPS fraction extracted during (A) winter and (B) summer campaigns. Bars represent the heterogeneity of the three sampling sites.

567 Figure 4. Comparison of carbohydrates quantities $\left(\mu \mathrm{g} \cdot \mathrm{g}\right.$ dry sediment ${ }^{-1}$ ) during winter and summer of the extracted EPS fractions, at the beginning of the emerged periods with their values at the end of the emerged period. Abbreviations W, S, LMW, HMW, CC, BC and RC

570 correspond respectively to winter, summer, low molecular weight, high molecular weight,

571 colloidal carbohydrates, bound carbohydrates and residual carbohydrates. Regression lines are 572 used to read the graphs. Data points in the upper left part correspond to variable which 573 increased over the emerged period; data points in the lower right part correspond to variable 574 which decreased during the same period. Data points close to the line: no change over the 575 emerged period. 
576 Figure 5. Monosaccharide composition $(\% \mathrm{w} / \mathrm{w})$ of the different fractions extracted in winter

577 and summer. See fig 4. for abbreviations meaning.

578 Figure 6. Principal component analysis scatter plot grouping monosaccharide profiles of the

579 different fractions along dominant sugar vectors. See fig 4. for abbreviations meaning.

580 Figure 7. Effect of the emersion time (average on the three sampling sites) on the major 581 monosaccharide contents. Glucose, xylose, galacturonic acid, rhamnose and fucose are 582 representative monosaccharides reported in fig. 6 as characteristics of the physicochemical 583 properties of the colloidal, bound and residual fractions. The variability within true sample 584 replicates was less than $5 \%$. See fig 4 . for abbreviations meaning. 
TABLE 1

\begin{tabular}{|c|c|c|c|c|c|c|c|c|c|c|}
\hline a) Winter & W-LMW CC & W-HMW CC & W-LMW BC & W-HMW BC & Light & Salinity & Pore water & $\begin{array}{c}\text { Bacterial } \\
\text { abundance }\end{array}$ & $\begin{array}{c}\text { Tidal } \\
\text { coefficient }\end{array}$ & $\mathrm{C}: \mathrm{N}$ \\
\hline Chl $a$ & -0.114 & 0.291 & -0.087 & 0.007 & 0,257 & 0,417 & 0.556 & -0.524 & -0.391 & nd \\
\hline W-LMW CC & $x$ & $0.656 *$ & $0.852 * *$ & -0.185 & $0.698 *$ & -0.387 & 0.083 & -0.323 & 0.200 & nd \\
\hline W-HMW CC & $x$ & $x$ & $0.795 * *$ & 0.276 & 0.347 & -0.393 & -0.176 & -0.126 & 0.427 & nd \\
\hline W-LMW BC & $x$ & $x$ & $x$ & 0.189 & 0.422 & $-0.733^{*}$ & -0.241 & -0.222 & 0.585 & nd \\
\hline W-HMW BC & $x$ & $x$ & $x$ & $x$ & -0.621 & -0.272 & -0.433 & 0.514 & $0.776 * *$ & nd \\
\hline Light & $x$ & $x$ & $x$ & $x$ & $x$ & 0.097 & 0.522 & $-0.682^{*}$ & -0.423 & nd \\
\hline Salinity & $x$ & $x$ & $x$ & $x$ & $x$ & $x$ & 0.618 & -0.008 & $-0.763^{*}$ & nd \\
\hline Pore water & $x$ & $x$ & $x$ & $x$ & $x$ & $x$ & $x$ & -0.558 & $-0.654^{*}$ & nd \\
\hline b) Summer & S-LMW CC & S-HMW CC & S-LMW BC & S-HMW BC & Light & Salinity & Pore water & $\begin{array}{c}\text { Bacterial } \\
\text { abundance }\end{array}$ & $\begin{array}{c}\text { Tidal } \\
\text { coefficient }\end{array}$ & $C: N$ \\
\hline Chl $a$ & 0.409* & 0.108 & -0.122 & $-0.375^{*}$ & 0.037 & 0.306 & $0.600 * * *$ & $0.405^{*}$ & 0.163 & 0.086 \\
\hline S-LMW CC & $x$ & -0.033 & -0.062 & 0.097 & 0.027 & 0.061 & $0.362^{*}$ & 0.307 & 0.091 & 0.090 \\
\hline S-HMW CC & $x$ & $x$ & $-0.576 * * *$ & -0.304 & 0.288 & 0.120 & 0.293 & -0.072 & $0.536 * * *$ & -0.175 \\
\hline S-LMW BC & $x$ & $x$ & $\mathrm{x}$ & 0.292 & 0.014 & 0.128 & $-0.338^{*}$ & -0.136 & -0.024 & -0.046 \\
\hline S-HMW BC & $x$ & $x$ & $x$ & $x$ & $-0.344 *$ & -0.249 & -0.090 & -0.114 & -0.267 & 0.163 \\
\hline Light & $x$ & $x$ & $x$ & $x$ & $\mathrm{x}$ & $0.330 *$ & -0.196 & -0.033 & $0.507 * *$ & -0.231 \\
\hline Salinity & $x$ & $x$ & $x$ & $x$ & $x$ & $x$ & $-0,421 *$ & 0.103 & $0.417 *$ & 0.066 \\
\hline Pore water & $x$ & $x$ & $x$ & $x$ & $x$ & $x$ & $x$ & 0.317 & -0.009 & -0.030 \\
\hline
\end{tabular}



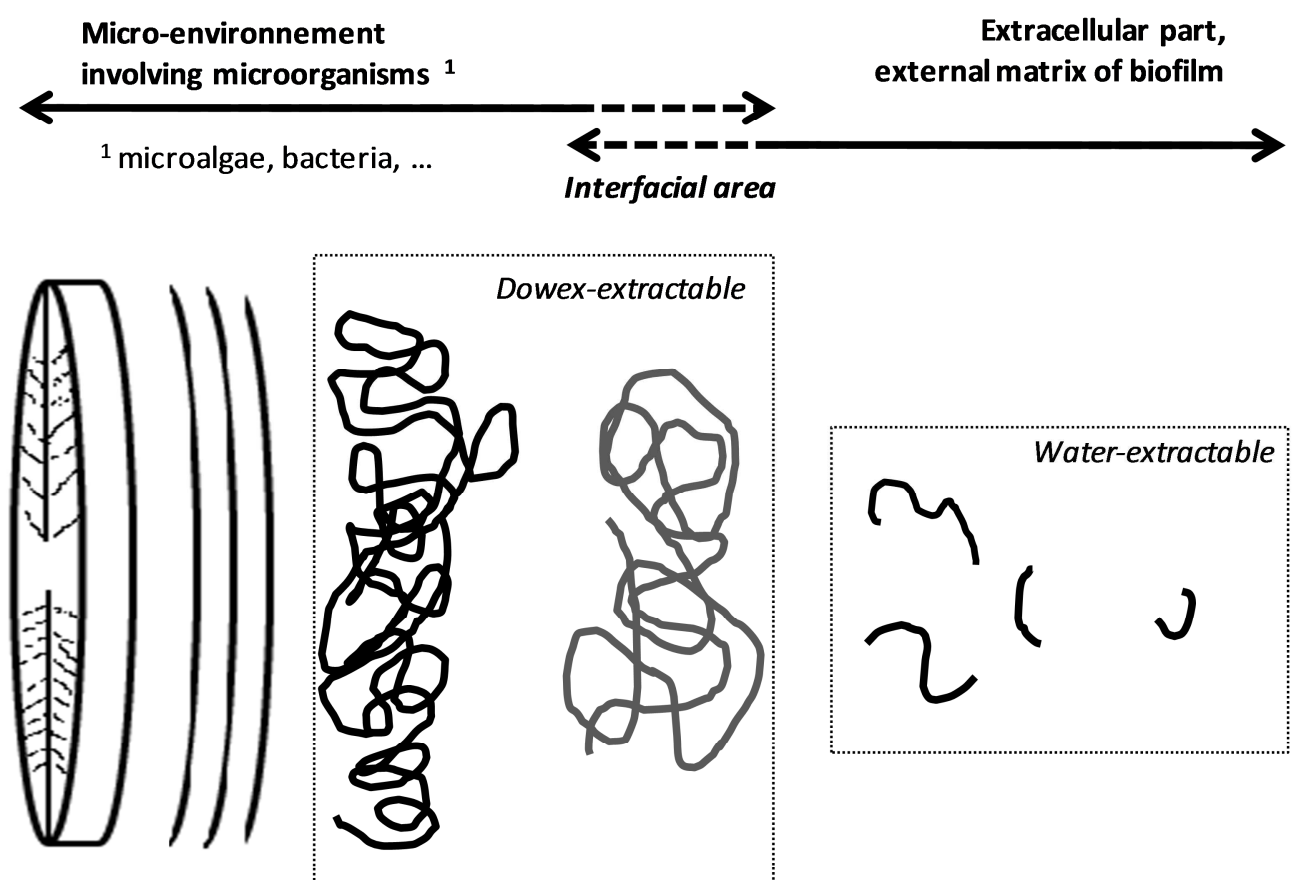

Interfacial area external matrix of biofilm 


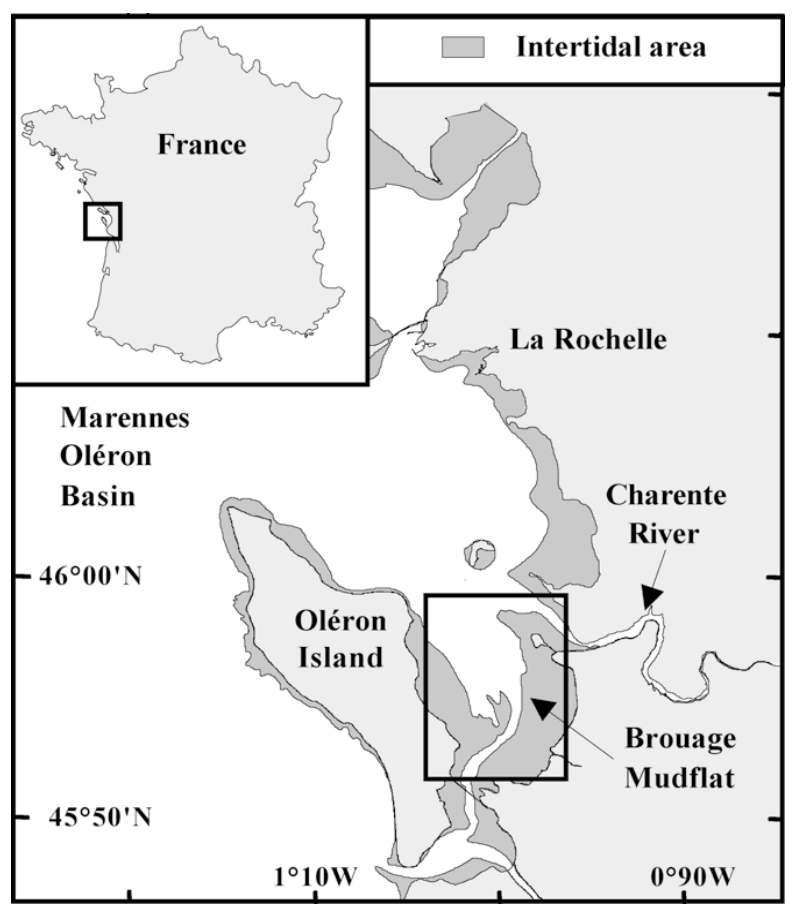

597

FIGURE 2

599 

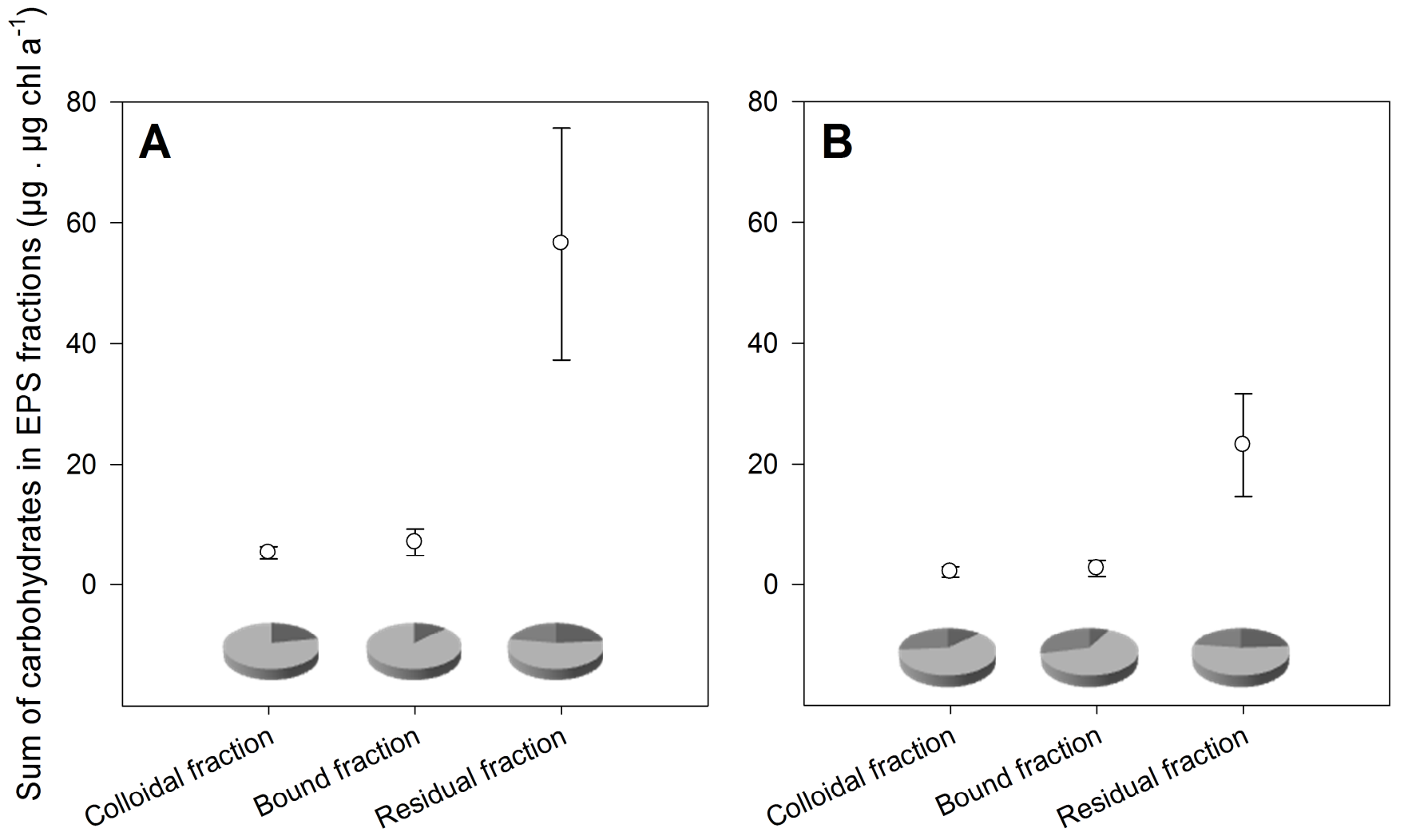

600

601

FIGURE 3

602 
WINTER (W)
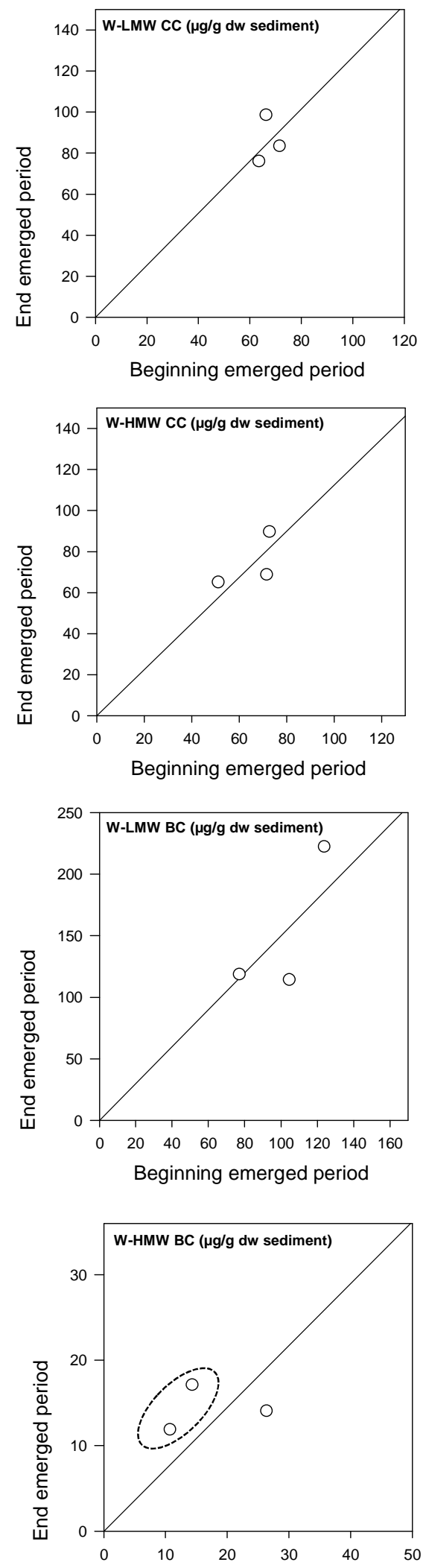

SUMMER (S)
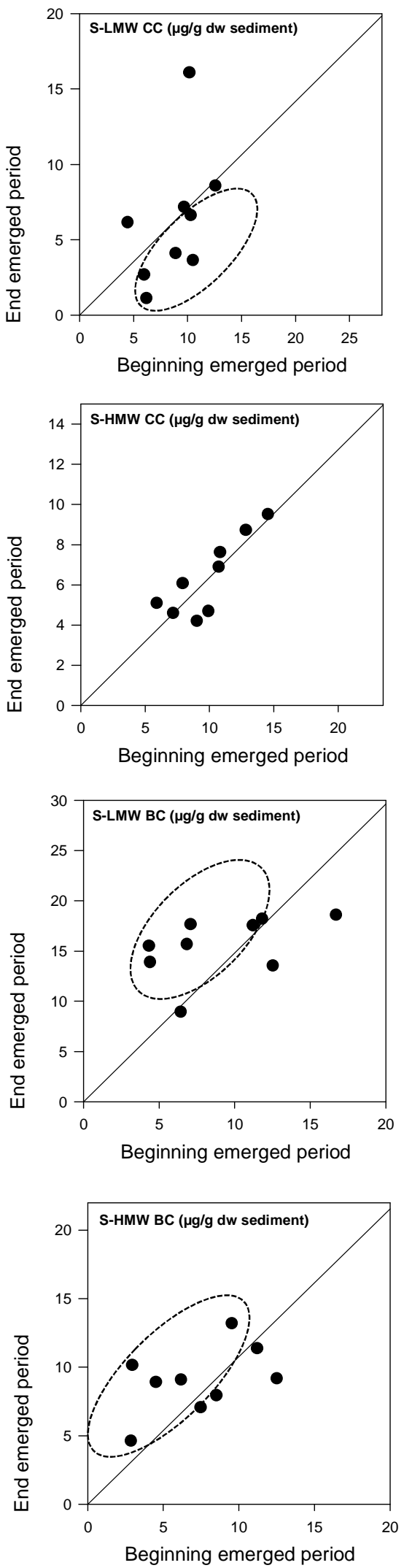

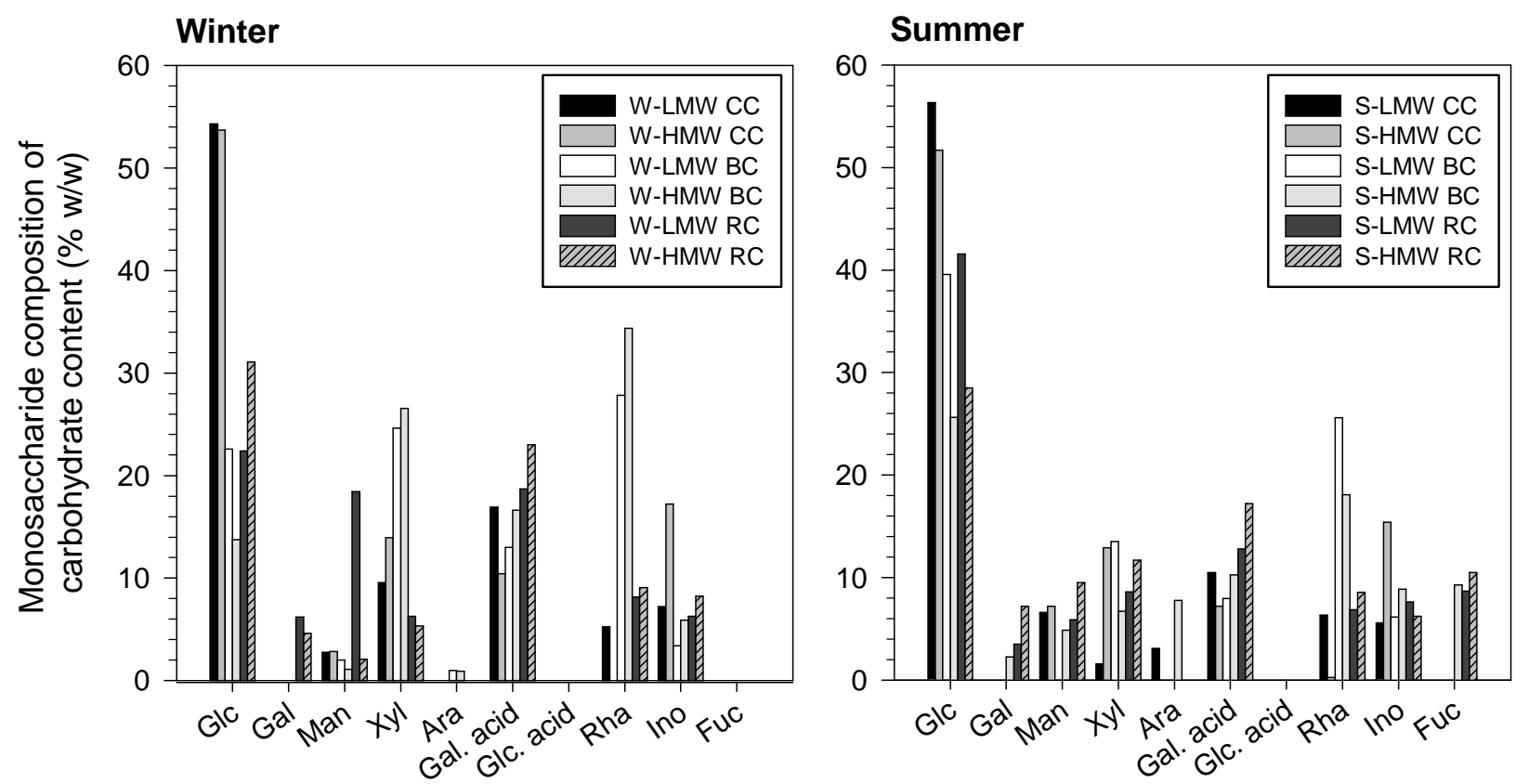

606

607

FIGURE 5

608 


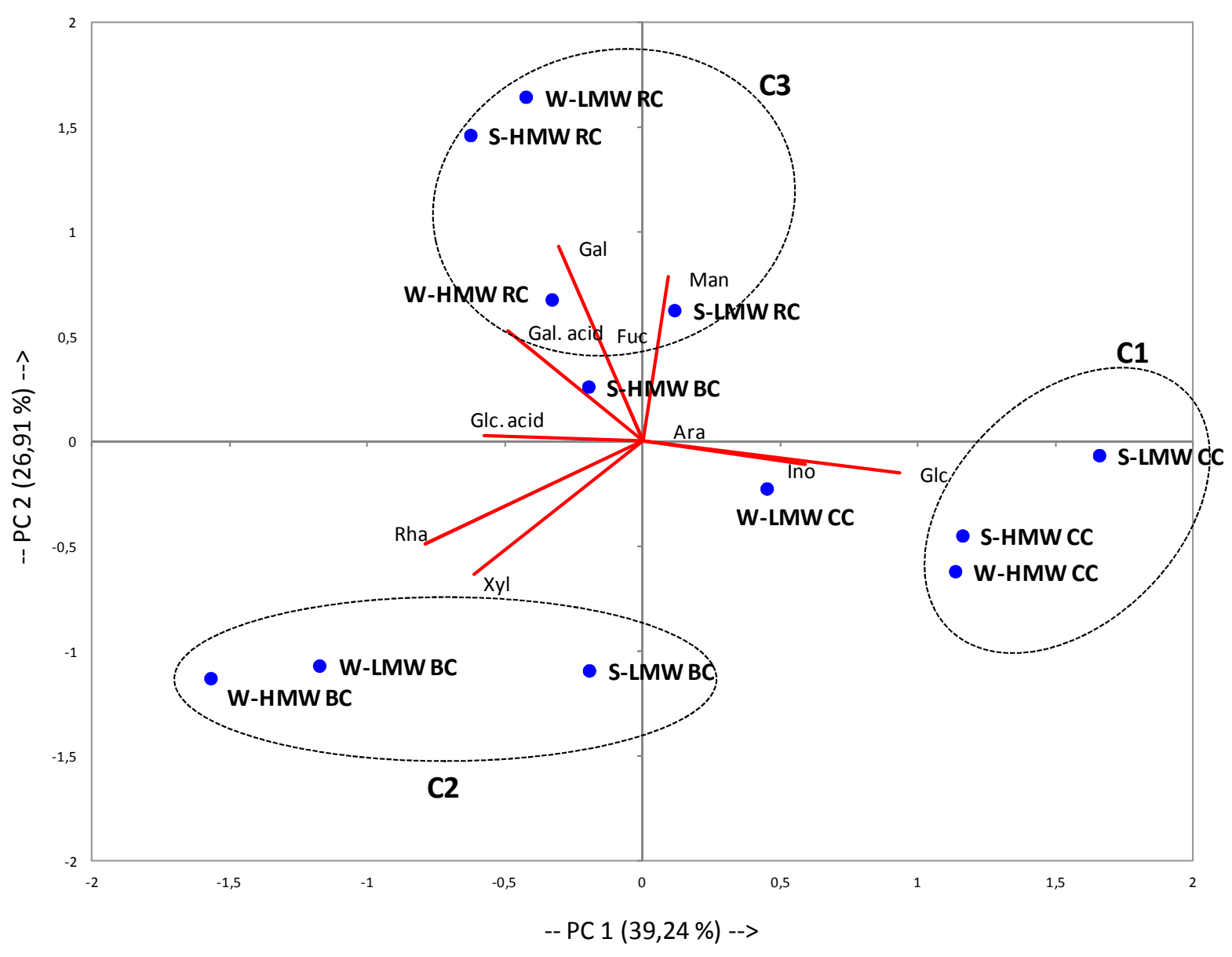

609 

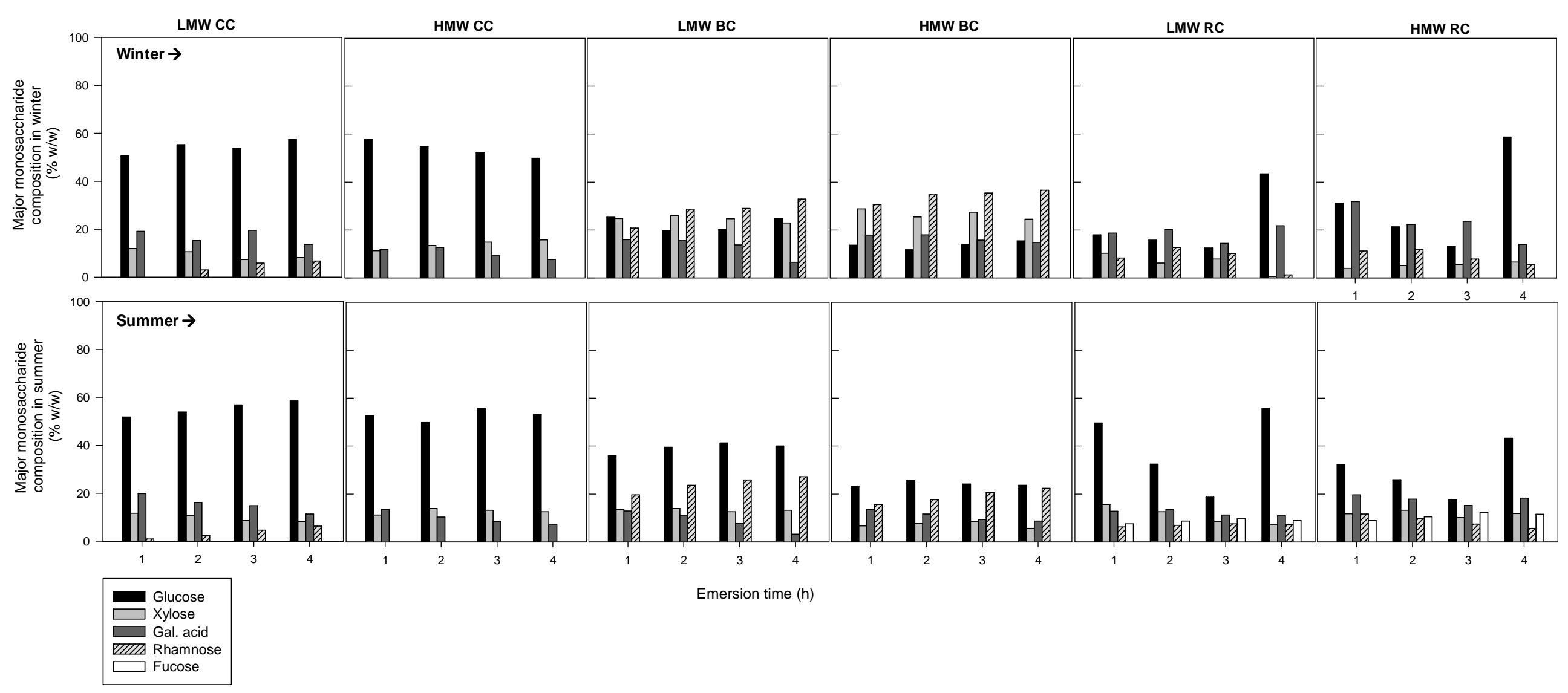

614 